\title{
The Effect of Guide Vane Opening Variations and Total Blades on Cross Flow Turbine Performance Using Computational Fluid Dynamic
}

\author{
Muhamad Akbar Navis, Heru Suryanto*, Putut Murdanto \\ Department of Mechanical Engineering, Universitas Negeri Malang, Jl. Semarang 5 Malang, \\ East Java, Indonesia \\ *Corresponding author: heru.suryanto.ft@um.ac.id
}

\begin{abstract}
Indonesia is an agrarian country that continuously produces water, so it has the potential to develop a hydroelectric power plant. Computational Fluid Dynamic (CFD) application could be used to be an economical, quick, and efficient approach to improve the engineering design and turbine performance. This research aimed to find the effect of guide vane opening variations and total blades on cross-flow turbine performance using CFD simulation. This research used experimental modelling method with ANSYS program for turbine design with 22,24 , and 26 turbine blades and guide vane opening variations of $12^{\circ}, 16^{\circ}$, $20^{\circ}, 24^{\circ}$, and $36^{\circ}$. The data were collected by reviewing the simulation results after the numerical calculation process. The results showed that the cross-flow turbine performance was improving along with the increasing guide vane opening. The optimum turbine performance (power and efficiency) was obtained at $24^{\circ}$ opening of guide vane and 26 total blades, producing $868.53 \mathrm{~W}$ power with $75.16 \%$ efficiency.

Copyright $@ 2020$. Journal of Mechanical Engineering Science and Technology.

All rights reserved.
\end{abstract}

Keywords: CFD, cross-flow turbine, guide vane opening, performance, total blades

\section{Introduction}

Currently, the overuse of fossil energy decreases the energy availability level. The situation is made aware by researchers who try to find various alternative energy. Hydroelectric power plant (HPP) exists and already used for more than one century as a source of energy and technology until now all over the world [1]. The electrical energy supply in Indonesia that is sourced from renewable energy is enormous due to the abundant water source and can be used as the source for Micro Hydro Power Plant (MHPP). MHPP is a small-scaled power plant (less than $200 \mathrm{~kW}$ ) that uses water flow as the energy source.

Water turbine utilizes the energy in the flow to create power in the form of electricity in the generator. Natural water, before streamed into the turbine, is put into a container then goes through a penstock or water channel and streamed into the turbine. During the flow process in the pipe, the potential energy of water gradually changes into kinetic energy [2]. In the turbine, water pounded or gave energy into the turbine blade that rotates the turbine shaft. In this condition, water kinetic energy transforms into mechanical energy in the form of turbine shaft rotation. Next, the turbine shaft was connected with the generator using a mechanical transmission.

Cross-flow impulse type turbine is one of the most used turbines for the microhydropower plant in Indonesia because it covers all locations with high water flow rate and low, medium, and high headwater. Cross-flow type turbine, also called the Banki turbine, 
has more advantages compared with the usage of the water wheel or other types of microhydro turbines [3]. The components that influence the performance of the cross-flow turbine, among others, are the total of blades and guide vanes, water flow rate, and head. The performance of the cross-flow turbine is known from the simulation analysis of runner and guide vane when the water flow hits the runner blade.

The CFD methodology emerged as an efficient approach to compile the information to improve the turbine engineering design because the CFD has a complex geometry, complex current, and more efficient duration [4]. The flow system and the power in the turbine were taken and drawn in the computer software to compare the power and efficiency results between the simulation and real results [5]. Thus, this research was conducted to find the effect of each guide vane opening variations and the variation of total blades on the torque, output, and efficiency as the performance characteristics of cross-flow turbine performance using the ANSYS computer software.

\section{Material and Methods}

This research used an experimental modelling method to analyse the effect of guide vane openings and total blades on the cross-flow turbine performance. The turbine model used referred to the cross-flow turbine. It was produced by CV. Hydro Cipta Mandiri type C4-24 (Lumajang, East Java) with a design flow rate of $0.3 \mathrm{~m}^{3} / \mathrm{s}$. It was performed variations on the independent variables of $12^{\circ}, 16^{\circ}, 20^{\circ}, 24^{\circ}$, and $36^{\circ}$ guide vane openings with 22,24 , and 26 total blades on the dependent variable of cross-flow turbine performance.

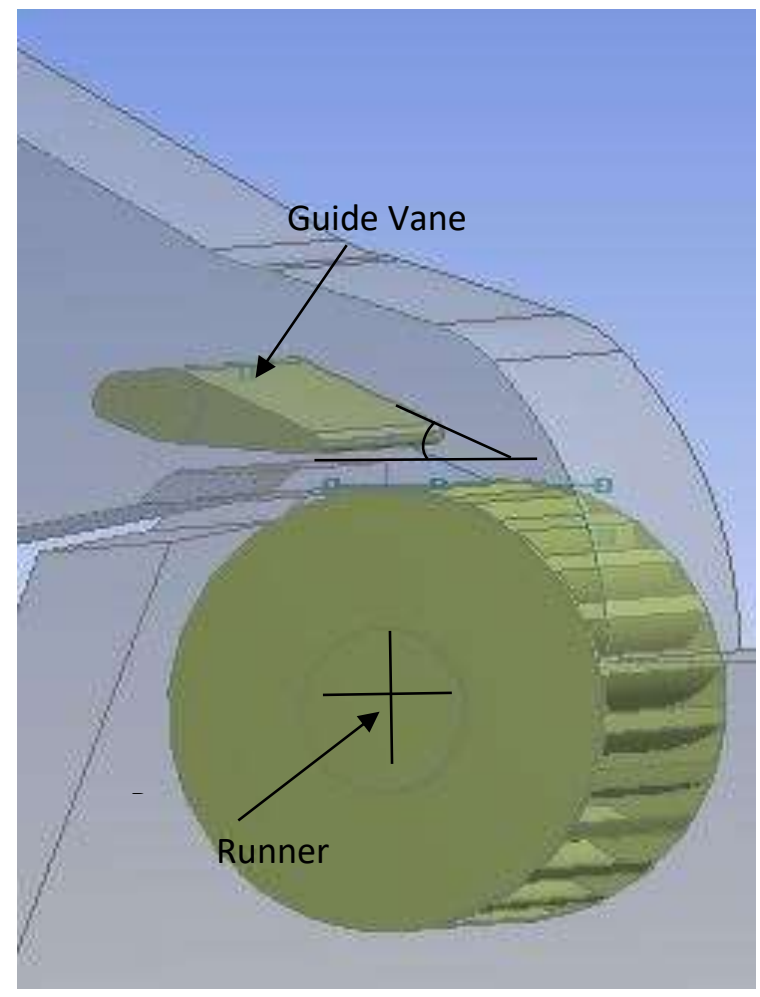

Fig. 1. Cross-flow turbine design 
The turbine runner had $240 \mathrm{~mm}$ diameter, $250 \mathrm{~mm}$ width, and $12^{\circ}$ angle emitting pipe. This research used the 2016 Autodesk Inventor Professional software. After the design was finished, the simulation and analysis were done using ANSYS workbench 14.5 with the fluent method to obtain the performance value (power and efficiency) from the cross-flow turbine. Figure 1 presents the cross-flow turbine design.

Figure 1 is the geometrical design of the cross-flow turbine with the guide vane opening $(\alpha)$ that can be controlled/varied following the electricity need in the society. The research object here was the cross-flow turbine performance (power and efficiency), of which the data was expected to be used in managing the power value on the electricity need in the society. The obtained data through reviewing the results were the outcome of numerical CFD and was processed using MS Excel 2016 to create the total value of cross-flow turbine performance on the simulation results. The performance value of cross-flow turbine was calculated using the formulation below:

$$
\begin{aligned}
& \mathrm{U}=(\pi \cdot \mathrm{D} \cdot \mathrm{n}) / 60 \\
& \mathrm{P}_{\mathrm{t}}=(\mathrm{T} \cdot 2 \cdot \pi \cdot \mathrm{n}) / 60 \\
& \mathrm{P}_{\mathrm{h}}=\rho \cdot \mathrm{Q} \cdot\left(\mathrm{v}^{\wedge} 2 / 2\right) \\
& \eta=\mathrm{P}_{\mathrm{t}} / \mathrm{P}_{\mathrm{h}} \quad \mathrm{x} 100 \%
\end{aligned}
$$

Where,

$$
\begin{aligned}
\mathrm{U} & =\text { Tangential speed }(\mathrm{m} / \mathrm{s}) \\
\mathrm{D} & =\text { Runner diameter }(0.24 \mathrm{~m}) \\
\mathrm{n} & =\text { Runner rotation speed }(\mathrm{rpm}) \\
\mathrm{P}_{\mathrm{t}} & =\text { Turbine power }(\mathrm{Watt}) \\
\mathrm{P}_{\mathrm{h}} & =\text { Hydraulic power }(\mathrm{Watt}) \\
\mathrm{T} & =\text { Torque }(\mathrm{Nm}) \\
\rho & =\text { Fluid density }\left(998.2 \mathrm{~kg} / \mathrm{m}^{3}\right) \\
\mathrm{Q} & =\text { Volumetric flow rate }\left(0.3 \mathrm{~m}^{3} / \mathrm{s}\right) \\
\mathrm{v} & =\text { Water velocity }(2.778 \mathrm{~m} / \mathrm{s}) \\
\eta & =\text { Turbine efficiency }(\%)
\end{aligned}
$$

The data analysis in this research used comparative descriptive method by describing the simulation results from the comparison of guide vane opening variations and total blades on the cross-flow turbine performance using the CFD simulation.

\section{Results and Discussions}

The data from CFD simulation were torque, tangential speed, water flow velocity, streamline, and pressure contour. Variables that were obtained from the numerical simulation using the CFD method was used in the calculation to get the cross-flow turbine performance values. The pressure moment data were obtained by reviewing the numerical simulation results that were used to calculate the performance values (power and efficiency) of the cross-flow turbine. The pressure moment value was assumed as the torque that was obtained from the simulation results. The chart below helps identify the simulation results. 
Figure 2 shows the torque values as a result of the numerical simulation using the fluent method that tends to increase along with the increasing guide vane openings and total blades. The lowest torque is obtained at the guide vane opening of $12^{\circ}$ and total blades amount of 22 with the value of $13.76 \mathrm{Nm}$ whereas the highest is obtained at the guide vane opening of $36^{\circ}$ and total blades amount of 26 with the value of $17.5 \mathrm{Nm}$. The guide vane openings in a range of $16^{\circ}$ to $20^{\circ}$, the torque has a significant improvement that greatly influenced the cross-flow turbine performance. A guide vane opening of $16^{\circ}$ with total blades amount of 26 , the torque value is $14.15 \mathrm{Nm}$, jumps up for $2.54 \mathrm{Nm}$ at guide vane opening of $20^{\circ}$.

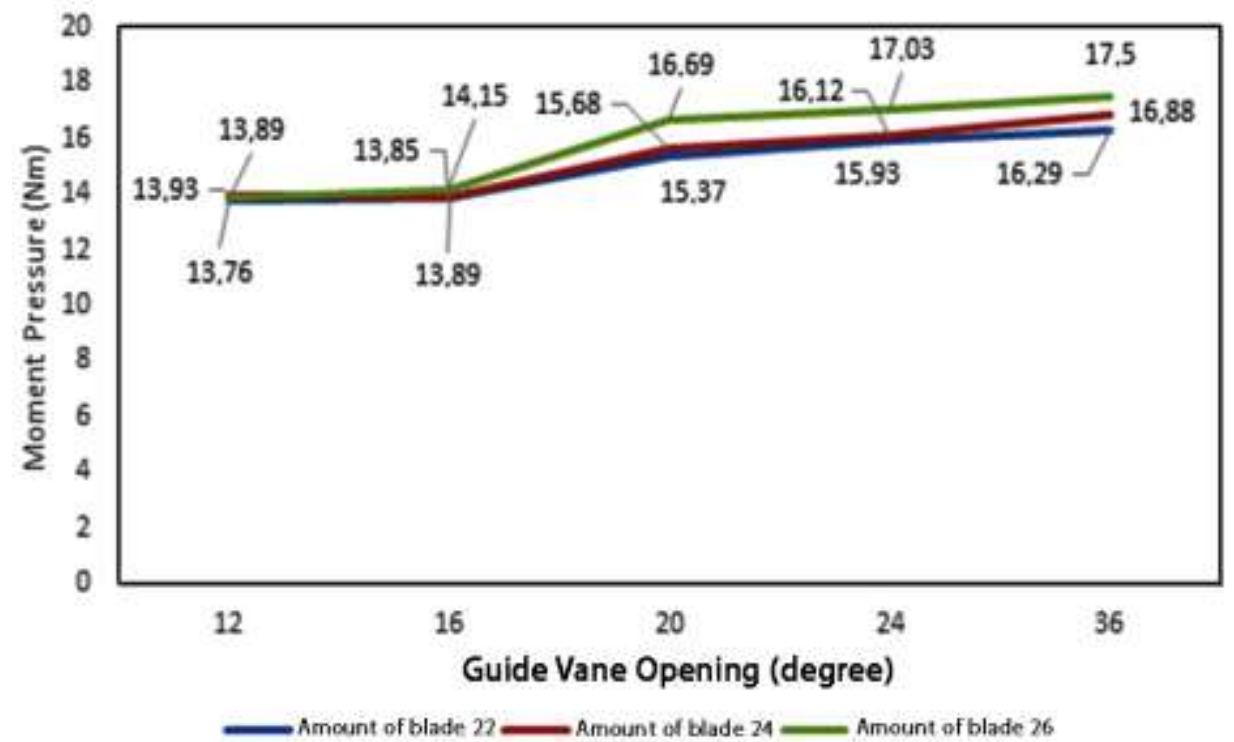

Fig. 2. Guide vane openings influence on the torque of cross-flow turbine

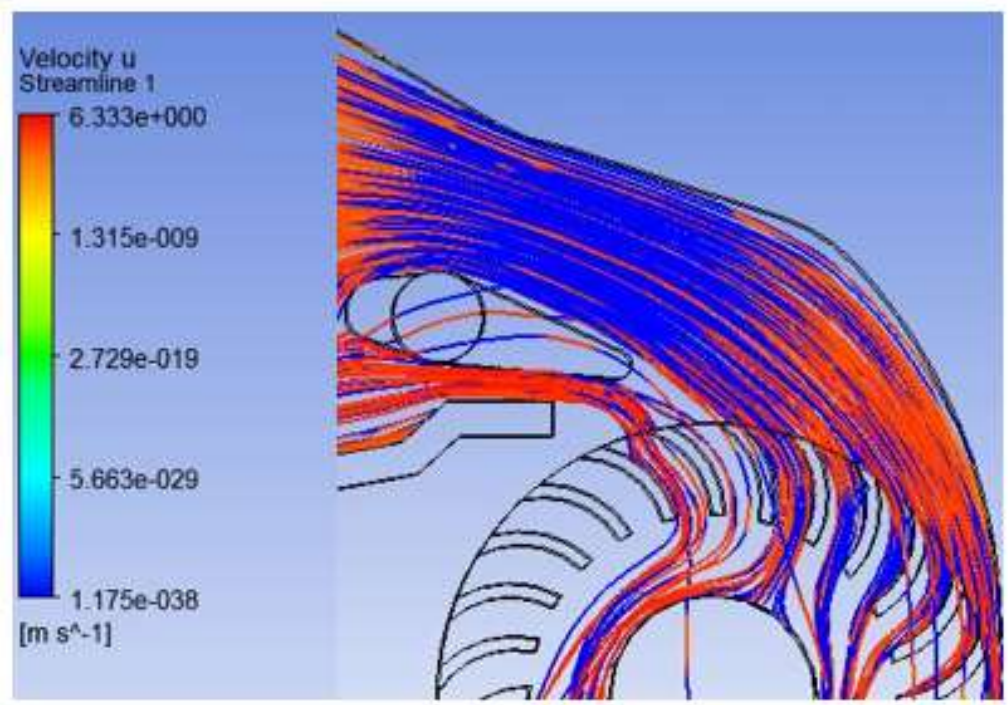

Fig. 3. Streamline simulation results

Figure 3 is the streamline simulation results at guide vane opening of $24^{\circ}$ and total blades amount of 24. It shows the turbine tangential velocity (U) of $6.333 \mathrm{~m} / \mathrm{s}$ by reviewing the 
value of the maximum tangential speed. Based on the formulation (1), Figure 4 shows the runner rotation speed value.

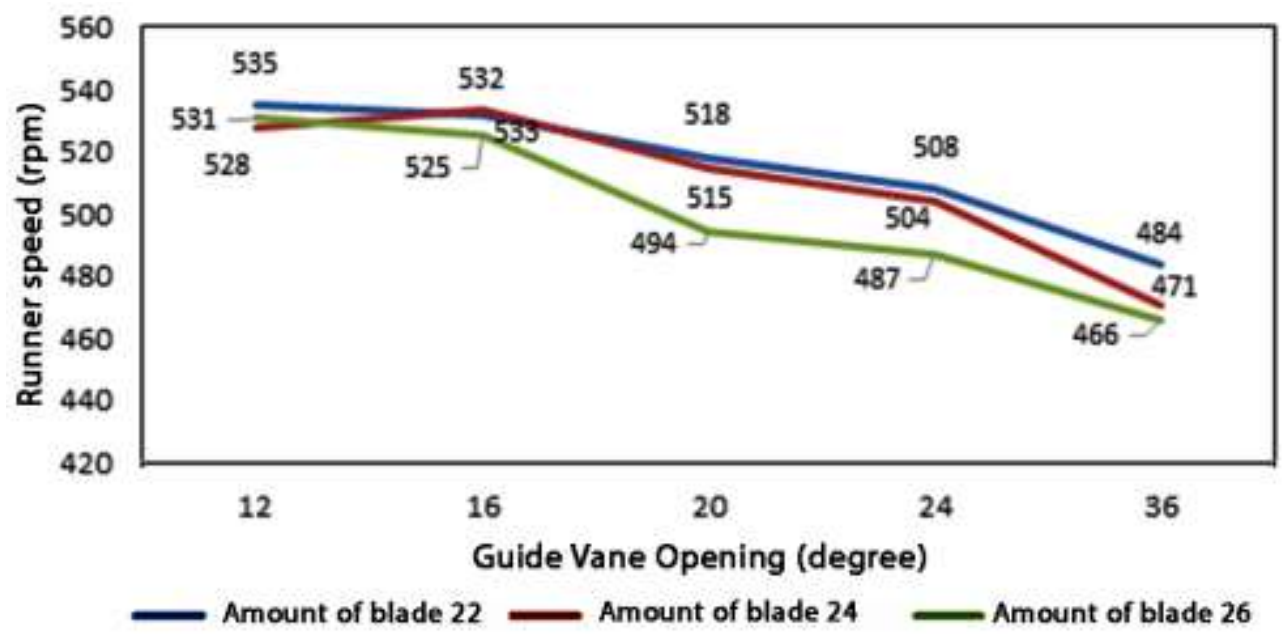

Fig. 4. Calculation results of cross-flow turbine runner rotation

Figure 4 shows the rotation chart that was produced by the turbine runner after simulation process at guide vane openings of $12^{\circ}, 16^{\circ}, 20^{\circ}, 24^{\circ}$, and $36^{\circ}$ and total blades amount of 22,24 , and 26 . It presents the decreasing runner rotation along with the increased torque in the simulation process because of the continuously decreasing loads.

At guide vane opening of $16^{\circ}$ with 26 blades, the runner rotation is $525 \mathrm{Rpm}$, then decreases up to $31 \mathrm{rpm}$ at $20^{\circ}$ due to the increases torque value at the same guide vane opening. This result is in line with other findings that show the influence of the variations of total blades on the cross-flow turbine performance, the efficiency test of cross-flow turbine runner with blades variations of 18,20 , and 22 resulted in the highest efficiency at 20 blades [5].

Turbine design variations for the optimum performance can be done by testing several parameters such as blade shape, guide vane opening, and total blades, of which those parameters affecting the power created by turbine generator, efficiency of the turbine, and performance. By conducting the CFD simulation, pressure contour in each blade that hit by the water is known and can be used to identify which blade greatly influences the power through the flow rate calculation in each blade.

In Figure 5, the yellow runner contour is a part with immense pressure and is assumed as the blade that influences the turbine power. For observing the effect of each blade, the water flow rate calculation in each runner blade was conducted. With total blades of 22 and 24 , the yellow contour appears in 6 blades. However, with 26 blades, the pressure that affects the turbine power is found in 7 runner blades. This situation occurred because, in 26 blades, the gap among the blades was narrower compared to the turbine with 22 and 24 blades. 

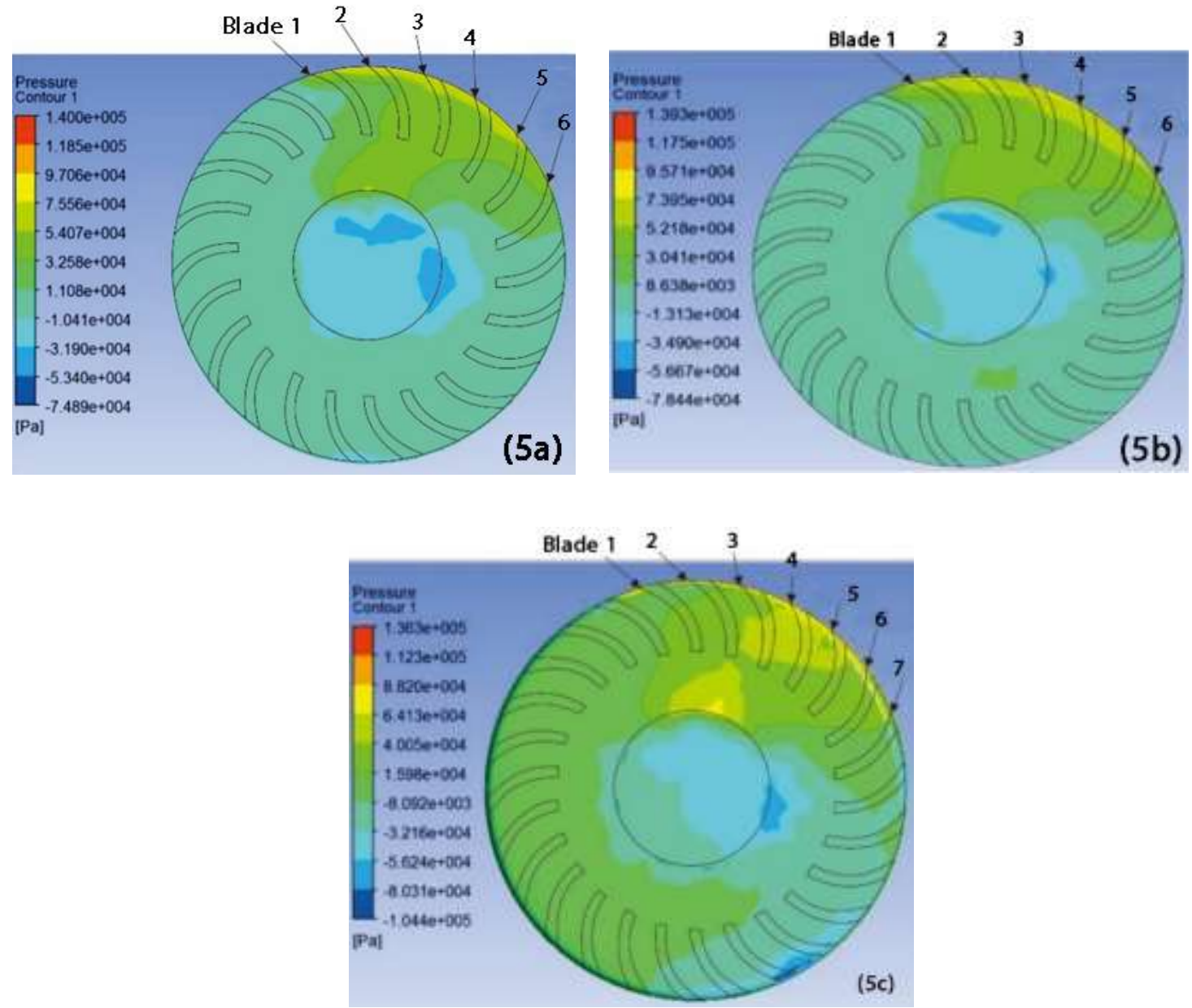

Fig 5. Turbine runner contour at $24^{\circ}$ guide vane opening with total blades amount of (a) 22 , (b) 24 , and (c) 26

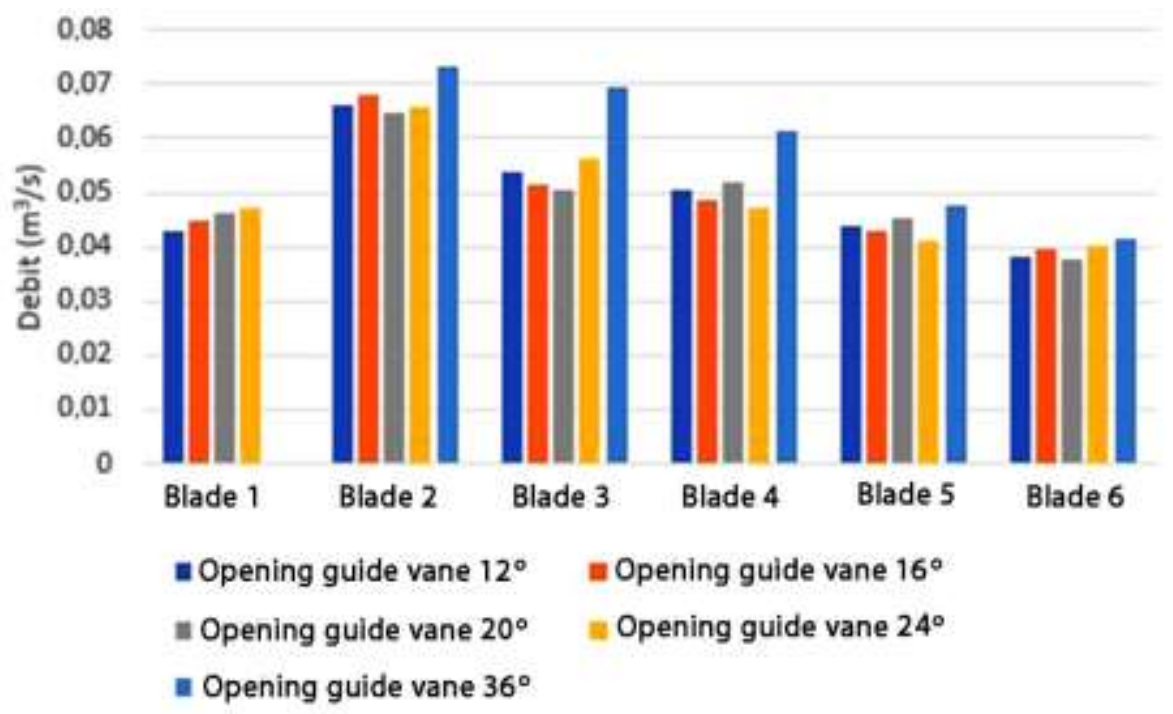

Fig. 6. Water flow rate input in each blade at 22 blades water turbine 
The flow rate calculation chart in the blade that influenced the runner power was shown in Figure 6. The highest flow rate and the largest influence is found in the blade 2. On blade 1 with guide vane opening of $36^{\circ}$ obtained the flow rate value of $0 \mathrm{~m}^{3} / \mathrm{s}$ because the lower nozzle of the guide vane was closed off entirely, so the water only passed the upper nozzle and hit the second blade.

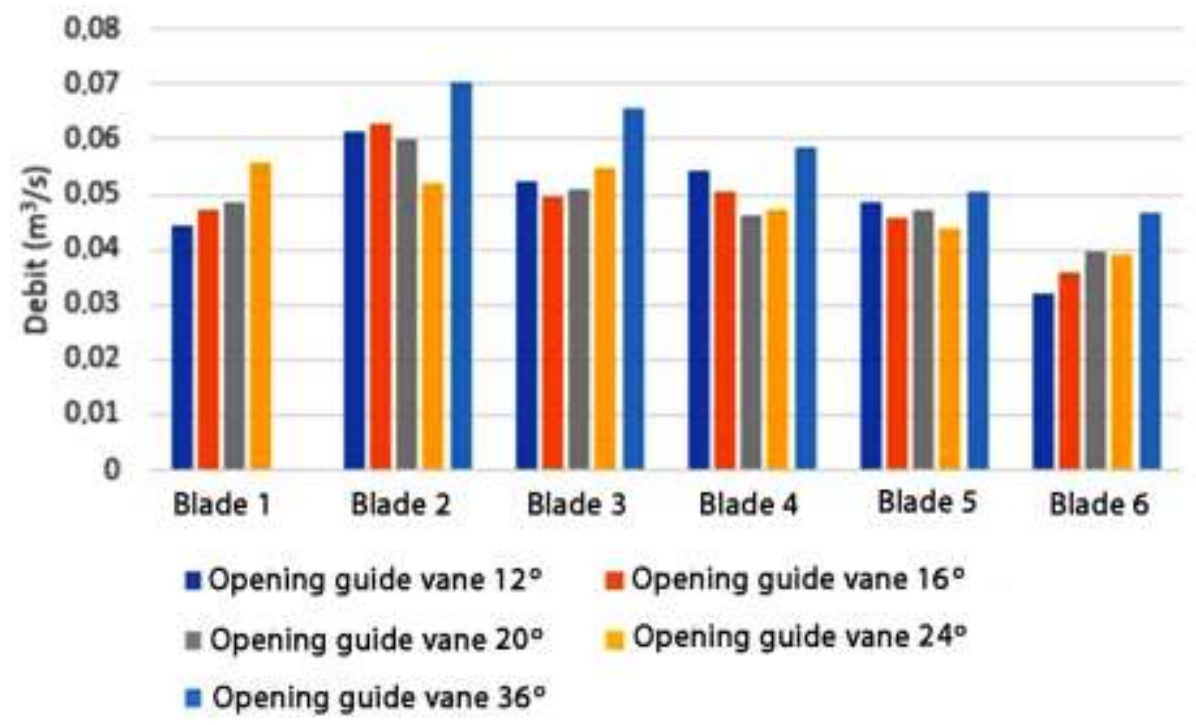

Fig. 7. Water flow rate input in each blade in 24 blades water turbine

Figure 7 shows that the highest flow rate and the largest influence is found in blades 2 . At blade 1 with guide vane opening of $36^{\circ}$ obtained the flow rate value of $0 \mathrm{~m}^{3} / \mathrm{s}$ because the lower nozzle of the guide vane was closed off entirely so that water only passed the upper nozzle and hit the second blade.

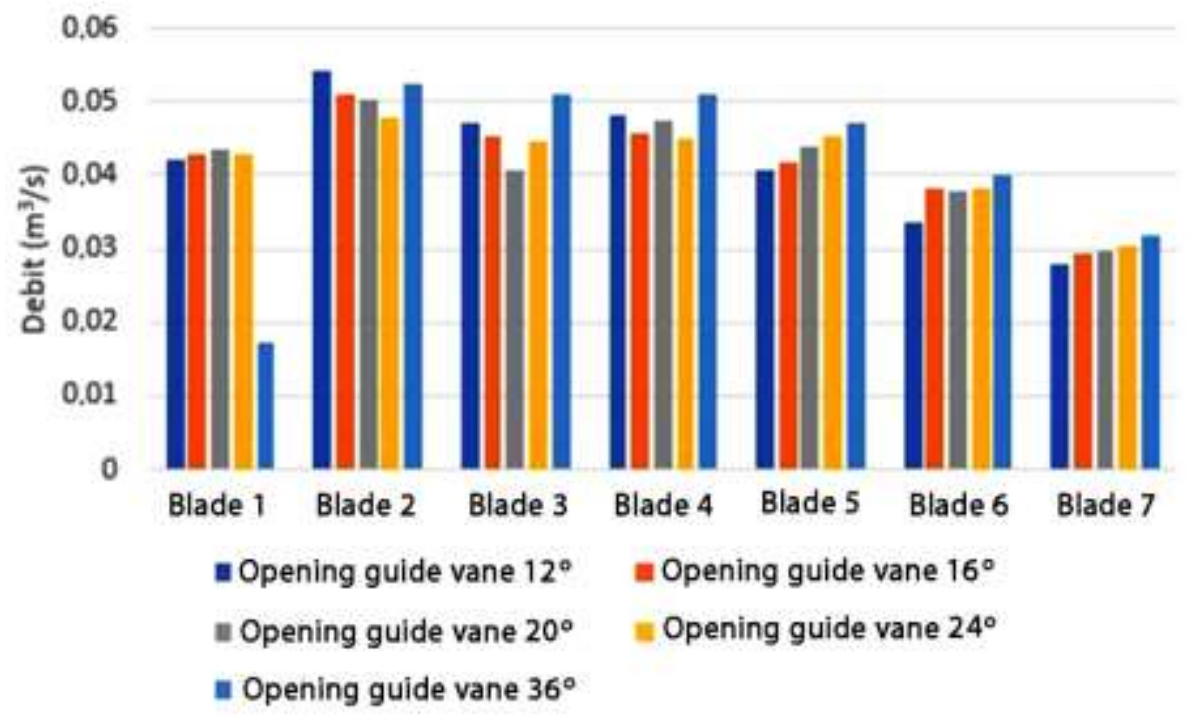

Fig. 8. Water flow rate input at each blade in 26 blades water turbine 
Figure 8 shows that the turbine with blade 2 and guide vane opening of $12^{\circ}$ generated the largest water flow rate of $0.054 \mathrm{~m}^{3} / \mathrm{s}$. There is a decrease of $0.007 \mathrm{~m}^{3} / \mathrm{s}$ at blade 3 . Meanwhile, the lowest flow rate occurred at blade 7 , with a value of $0.0278 \mathrm{~m}^{3} / \mathrm{s}$. At $16^{\circ}$ guide vane opening, blade 1 turbine created in $0.0429 \mathrm{~m}^{3} / \mathrm{s}$ flow rate, and there was an increase of $0.0082 \mathrm{~m}^{3} / \mathrm{s}$ of flow rate in blade 2 . At $20^{\circ}$ guide vane opening, the largest flow rate occurs with blade 2 with the value of $0.0504 \mathrm{~m}^{3} / \mathrm{s}$, whereas at $24^{\circ}$ opening, the largest flow rate occurs with blade 2 for $0.0478 \mathrm{~m}^{3} / \mathrm{s}$.

In correlation with the guide vane opening variations on the cross-flow turbine performance, the turbine power and efficiency could be varied according to the water flow rate and not the guide vane opening. The maximum efficiency of $89 \%$ was obtained at the middle position and $30.5^{\circ}$ guide vane angle [6]. Guide vane opening with the angle between guide vane and turbine runner and produced the highest power and efficiency of $75.16 \%$ at $24^{\circ}$ guide vane opening [7]. Turbine shaft power is a power that was created by the turbine to drive the generator in its application. Turbine power can be calculated using formulation (2) with the results presented in Figure 9.

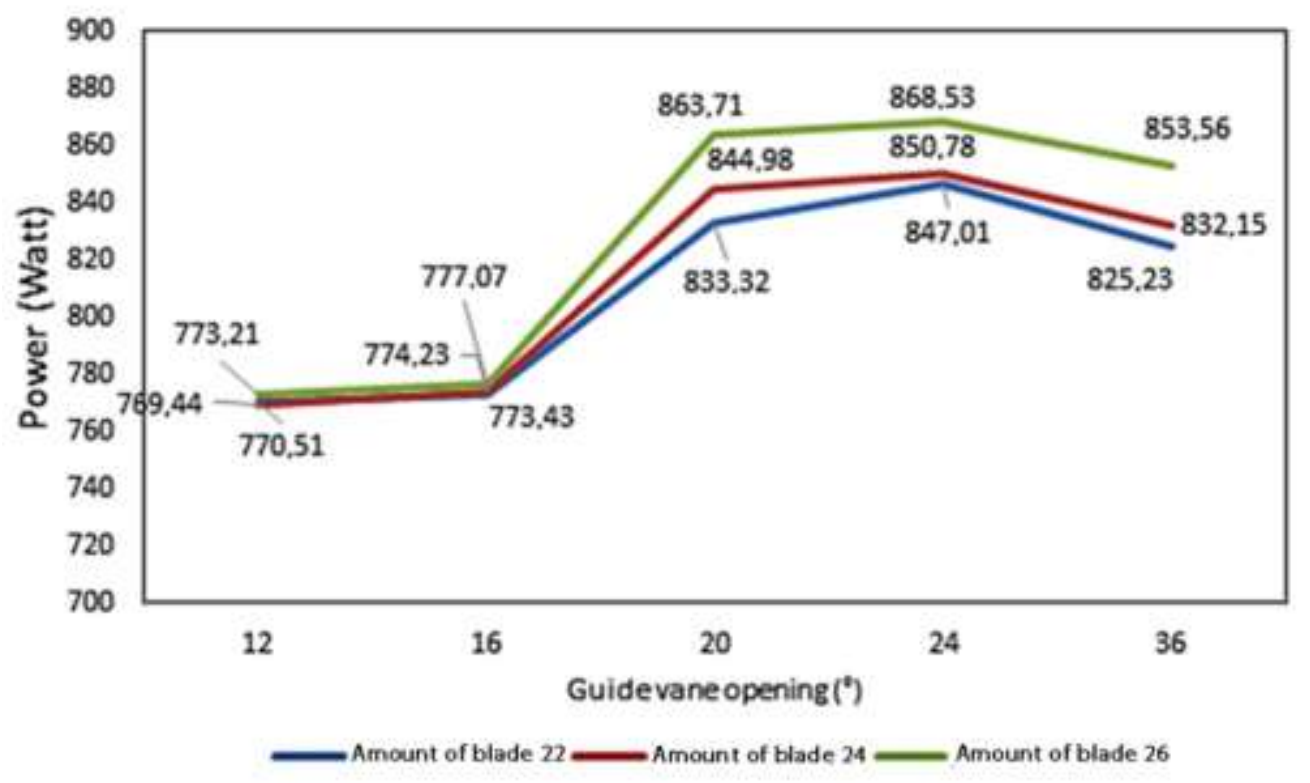

Fig. 9. Guide vane opening influence on cross-flow turbine performance

Figure 9 shows the variations of guide vane opening of $12^{\circ}, 16^{\circ}, 20^{\circ}, 24^{\circ}$, and $36^{\circ}$ with total blades of 22, 24, and 26. The turbine power tends to increase along with the additional opening. However, at the maximum opening of $36^{\circ}$, turbine power experiences a decrease due to stream turbulence in the guide vane area caused by a closed lower nozzle from the guide vane so that the tangential flow speed also decreased.

The sharp increase occurred at $16^{\circ}$ to $20^{\circ}$ guide vane opening. This phenomenon can be utilized to control the desired power following electricity consumption by society in its application. At noon, the electricity consumption tends to be low so that the guide vane can be managed at $12^{\circ}$ to $16^{\circ}$. At night, the consumption is high and requires larger power; hence, the guide opening is adjusted at $20^{\circ}$ to $24^{\circ}$.

The lowest turbine power is obtained at guide vane opening of $12^{\circ}$ with 22 total blades with a value of 770.51 watts. Meanwhile, the largest turbine power was obtained at $24^{\circ}$ guide vane opening with 26 total blades and resulted in 868.53 watts. 
Hydraulic power is the power that enters the turbine in the form of water potential power. The total value of hydraulic in this research was calculated using equation (3) and was obtained $1155.509 \mathrm{~W}$ value. Meanwhile, turbine efficiency was found from the comparison between turbine power $(\mathrm{Pt})$ with hydraulic power $(\mathrm{Ph})$ times $100 \%$. The turbine value $(\mathrm{Pt})$ and hydraulic power $(\mathrm{Ph})$ were known from the previous calculation. Figure 10 presents the results of the efficiency calculation.

Figure 10 displays the turbine efficiency at $12^{\circ}, 16^{\circ}, 20^{\circ}, 24^{\circ}$, and $36^{\circ}$ openings with 22,24 , and 26 blades. Turbine efficiency increases along with the additional guide vane openings and total blades. However, at $36^{\circ}$ opening, the efficiency experiences a reduction. The efficiency decrease occurs because of the closed-off lower nozzle that made current turbulence in the guide vane and caused a decrease in the absolute speed that also caused a decrease in the turbine runner rotation; hence, turbine power and efficiency also decreased.

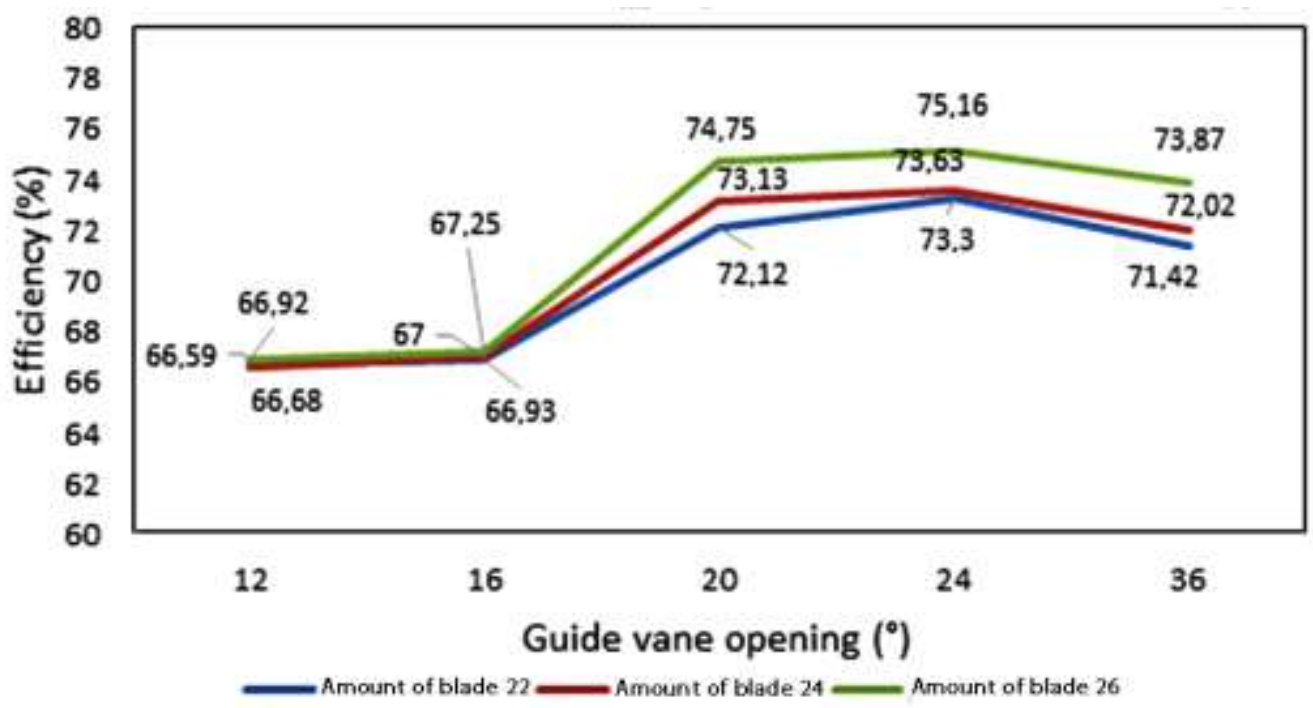

Fig. 10. The effect of guide vane opening on cross-flow turbine efficiency

At $16^{\circ}$ to $20^{\circ}$ guide vane opening, the efficiency sharply increases with the value of $67.25 \%$ at $16^{\circ}$ opening and increases for $7.50 \%$ at $20^{\circ}$ opening. The improvement can be used to control the guide vane opening by adjusting the high and low electricity consumption in society at certain times. The lowest efficiency is found at $12^{\circ}$ opening and 24 blades with a value of $66.59 \%$. Meanwhile, the highest efficiency was found at $24^{\circ}$ opening and 26 blades with a value of $75.16 \%$.

The high turbine efficiency occurred because, during the $24^{\circ}$ guide vane opening, the flow rate that flew in the upper nozzle of guide vane was larger so that the power that arose from the water to runner blade impact was more extensive. The torque was also larger because the length blade was constant and the efficiency at $26^{\circ}$ occurred because, at that opening, the gap between the blades was shorter and narrower and made the water flow rate that entered the gap larger; thus reducing the chance of air to fill the gap between the blades. Besides, the larger contraction value between water impact on the blade created higher torque, power, and efficiency values. The efficiency that was obtained from this research was lower than the efficiency from Khosrowpanah research [8], where he used the CFD simulation to achieve efficiency of $80 \%$. Performed analysis by simplifying the screw of guide vane in a cross-flow turbine and achieved $79 \%$ efficiency [9]. 


\section{Conclusions}

The CFD analysis to guide vane opening variations and total blades had been conducted. It can be concluded that guide vane opening variations and total blades affecting the crossflow turbine performance (power and efficiency). Turbine performance increased following the additional guide vane opening. The optimum value for turbine performance was obtained in 26 blades and $24^{\circ}$ opening with a value of 868.53 watts and $75.16 \%$ efficiency. Based on the characteristics of turbine power and efficiency that were generated, technically, $12^{\circ}$ to $16^{\circ}$ guide vane opening had a significant impact on the increase of turbine power. Thus, this range can be used as the technical reference setting in adjusting the fluctuating electricity consumption.

\section{References}

[1] Zimny, J., Michalak, P., Bielik, S., and Szczotka, K., "Direction in Development of Hydropower in the World, in Europe and Poland in the Period 1995-2011", Renewable and Sustainable Energy Reviews, vol. 21, pp. 117-130, 2013.

[2] Munandar, A.W., Penggerak Mula Turbin, ITB Bandung, Bandung, 1982, pp.10-14

[3] Larasakti, A.A., Himran, S., and Arifin, A.S., "Pembuatan dan Pengujian Pembangkit Listrik Tenaga Mikrohidro Turbin Banki Daya 200 Watt”, Jurnal Mekanikal, vol. 3(1), pp. 2-4, 2012.

[4] Gohil, P., and Saini, R. P., "Numerical Study of Cavitation in Francis Turbine of a Small Hydro Power Plant", Journal of Applied Fluid Mechanics, vol. 9(1), pp.357-365, 2016.

[5] Chiyembekezo, S.K., Cuthbert, Z.K., and Torbjorn, K.N., "Experimental Study on a Simplified Crossflow Turbine", International Journal of Energy and Environment, vol. 5(2), pp. 2-12, 2014.

[5] Sugiri, A., Burhanudin, H., and Trinando, E., "Studi Kelayakan Pembangkit Listrik Tenaga MikroHidro (PLTMH) pada Sungai Arter Desa Hurun Kecamatan Padang Cermin Kabupaten Pesawaran Lampung”, Jurnal Mechanical, vol. 4(2), pp. 2-5, 2015.

[6] Salman, A., Shoukat, A., Naif A., Tahir, M.H., Shahid, M., Razzaq, S., Sabri, M.A., Asghar, M.A., Saeed, M.W., Waqas, M., "Experimental Evaluation on Performance of Novel Cross-flow Impulse Turbine for Water Stream in Hilly Areas of Pakistan", International Journal of Renewable Energy Research, vol. 9(4), pp.1782-1789, 2019.

[7] Haurissa, J., Wahyudi, S., Irawan, Y.S., and Soenoko, R., "The Cross Flow Turbine Behavior towards the Turbine Rotation Quality, Efficiency, and Generated Power", Journal of Applied Sciences Research, vol. 8(1), pp. 448-453, 2012.

[8] Khosrowpanah, S., Fiuzat, A.A., Albertson, M.L., "Experimental Study of Cross Flow Turbine", Journal Hydraulic Engineering, vol.114, pp. 299-314, 1988.

[9] Chiyembekezo, S.K, Cuthbert, Z.K., and Torbjorn, K.N., "A Numerical Investigation of Flow Profile and Performance of a Low Cost Crossflow Turbine", International Journal of Energy and Environment, vol. 5(3), pp. 23-25, 2014. 